\title{
Activin A: An Autocrine Inhibitor of Initiation of DNA Synthesis in Rat Hepatocytes
}

\author{
Hiroshi Yasuda, Tetsuya Mine, * Hiroshi Shibata, Yuzuru Eto, ${ }^{\ddagger}$ Yoshihisa Hasegawa, \\ Toshiyuki Takeuchi, Shigetaka Asano, ${ }^{*}$ and Itaru Kojima \\ Cell Biology Research Unit, Institute of Endocrinology, Gunma University, Maebashi 371, Japan; *Fourth Department of Internal \\ Medicine, University of Tokyo School of Medicine, Tokyo 112, Japan; ${ }^{\ddagger}$ Central Research Laboratory, Ajinomoto Ltd., Kawasaki 210 , \\ Japan; and ${ }^{\S}$ Department of Obstetrics and Gynecology, Gunma University School of Medicine, Maebashi 371, Japan
}

\begin{abstract}
The present study was conducted to examine the effect of activin $A$ on growth of rat hepatocytes. EGF induced a 10-fold increase in DNA synthesis as assessed by [ $\left.{ }^{3} \mathrm{H}\right]$ thymidine incorporation in cultured hepatocytes. When activin $A$ was added together with EGF, DNA synthesis induced by EGF was markedly inhibited. Inhibition was detected at a concentration of $10^{-10} \mathrm{M}$, and $5 \times 10^{-9} \mathrm{M}$ activin $\mathrm{A}$ almost completely blocked EGF-mediated DNA synthesis. Similarly, activin A completely blocked DNA synthesis induced by hepatocyte growth factor/ scatter factor. Activin A was capable of inhibiting EGF-mediated DNA synthesis, even when added $36 \mathrm{~h}$ after the addition of EGF. With the same time interval, TGF- $\beta$ also blocked EGF-induced DNA synthesis. Although both activin $A$ and TGF $-\beta$ inhibited growth of hepatocytes in a similar manner, either activin A or TGF- $\beta$ did not compete with each other in their binding when assessed by competitive binding using an iodinated ligand. When hepatocytes were incubated with EGF, release of bioactivity of activin $A$ into culture medium was detected after $48 \mathrm{~h}$ or later. Activity of activin $A$ was released from parenchymal cells but not from nonparenchymal cells. mRNA for $\beta_{\mathrm{A}}$ subunit of activin was detected only slightly in unstimulated hepatocytes, but markedly increased at $48 \mathrm{~h}$ after the addition of EGF. To determine whether endogenously produced activin A affects DNA synthesis, we examined the effect of follistatin, an activin-binding protein that blocks the action of activin A. An addition of follistatin significantly enhanced EGF-induced DNA synthesis. Finally, in partial hepatectomized rat, expression of mRNA for $\beta_{A}$ subunit in liver was markedly increased $24 \mathrm{~h}$ after the partial hepatectomy. These results indicate that activin A inhibits initiation of DNA synthesis in hepatocytes by acting on its own receptor and that activin $A$ acts as an autocrine inhibitor of DNA synthesis in rat hepatocytes. (J. Clin. Invest. 1993.92:1491-1496.) Key words: parenchymal liver cells $\bullet$ transforming growth factor- $\beta$ - follistatin • inhibin
\end{abstract}

\section{Introduction}

Activin A is a homodimeric protein with molecular mass of 25 $\mathrm{kDa}$ (1). Structure of activin A shares homology with TGF- $\beta$ and activin $A$ is now considered to be a member of TGF- $\beta$

Address correspondence and reprint requests to Itaru Kojima, M.D., Institute of Endocrinology, Gunma University, Maebashi 371, Japan. Received for publication 23 November 1992 and in revised form 15 April 1993

J. Clin. Invest.

(c) The American Society for Clinical Investigation, Inc.

$0021-9738 / 93 / 09 / 1491 / 06 \$ 2.00$

Volume 92, September 1993, 1491-1496 supergene family. In accordance with this notion, activin A elicits diverse effects in various types of cells. In particular, activin A modifies growth and differentiation of target cells. Thus, activin A increases number of gonadotrophs in pituitary (2) and modulates differentiation of ovarian granulosa cells (3, 4). In addition to the actions on pituitary-gonadal axis, activin A induces differentiation of erythroid cells (5) and megakaryocytes (6), modifies growth and differentiation of neuronal cells $(7,8)$, and acts as an inducer of mesoderm during development (9-11).

We have reported that isolated rat hepatocytes produce glucose in response to activin A (12), an observation indicating that parenchymal liver cells are one of target cell systems of activin A. It is shown that TGF- $\beta$ is a potent inhibitor of cell growth in parenchymal liver cells in primary culture (13). During liver regeneration, mRNA for TGF- $\beta$ is expressed in nonparenchymal cells of the liver (14). TGF- $\beta$ is thus synthesized in nonparenchymal cells and is secreted probably as an inactive form. Although the mechanism of activation of TGF$\beta$ in liver is not totally understood, it is postulated that TGF- $\beta$ acts as a paracrine growth inhibitor of hepatocytes. Since activin A modulates cell growth and differentiation in many cell systems, and since hepatocytes possess a receptor system for activin $\mathrm{A}$, it is an interesting possibility that activin $\mathrm{A}$ also modifies growth of hepatocytes. In the present study, we examined the effect of activin A on DNA synthesis in cultured rat hepatocytes. We report here that activin A is a potent inhibitor of initiation of DNA synthesis in rat parenchymal liver cells. Furthermore, activin A is synthesized and is released from hepatocytes when the growth is stimulated by either EGF or hepatocyte growth factor (HGF) ${ }^{1} /$ scatter factor. Hence, activin A acts as an autocrine negative regulator of DNA synthesis in parenchymal liver cells and presumably plays a significant role in the regulation of hepatocyte growth.

\section{Methods}

Materials. Recombinant human activin A was obtained as described previously (15). Recombinant human follistatin was provided by Prof. M. Muramatsu of Saitama Medical College. Human recombinant HGF/Scatter Factor (16) was provided by Prof. T. Nakamura of Osaka University (Osaka, Japan). Human recombinant TGF- $\beta_{1}$ was purchased from King Jozo (Himeji, Japan). Bovine inhibin A was purified from ovarian follicular fluid as described previously (17). EGF was obtained from Collaborative Research (Lexington, MA). $\left[{ }^{3} \mathrm{H}\right]$ Thymidine $(6.7 \mathrm{Ci} / \mathrm{mmol})\left[{ }^{32} \mathrm{P}\right] \mathrm{UTP},\left[{ }^{35} \mathrm{~S}\right] \mathrm{UTP}$, and $\left[{ }^{125} \mathrm{I}\right]-$ TGF- $\beta(1,500 \mathrm{Ci} / \mathrm{mmol})$ were purchased from Du Pont New England Nuclear (Boston, MA). Nucleotide probes for rat inhibin subunits were provided by Dr. Ling of The Salk Institute (La Jolla, CA).

1. Abbreviation used in this paper: HGF, hepatocyte growth factor. 
Preparation and culture of hepatocytes. Male Wistar rats (170$200 \mathrm{~g}$ ) were used for all experiments. Rat parenchymal liver cells were prepared by the method of Berry and Friend (18). Cells were plated in a 24-well collagen-coated dish at a density of $5 \times 10^{4} /$ well in Williams' E medium containing 5\% fetal bovine serum, $10 \mathrm{nM}$ insulin, $1 \mathrm{nM}$ dexamethasone, streptomycin, and penicillin unless otherwise mentioned. After $3 \mathrm{~h}$, cells were washed and were then incubated in fresh serum-free medium containing $0.1 \mathrm{nM}$ insulin, $0.1 \% \mathrm{BSA}$ and either EGF ( $1 \mathrm{nM})$ or HGF/scatter factor $(10 \mathrm{ng} / \mathrm{ml})$. Nonparenchymal liver cells were cultured as described by Shimaoka et al. (19). Partial hepatectomy (70\%) as described by Higgins and Anderson (20) was performed under ether anesthesia.

Measurement of DNA synthesis. DNA synthesis was assessed by measuring $\left[{ }^{3} \mathrm{H}\right]$ thymidine incorporation into trichloroacetic acid-precipitable materials. Hepatocytes were incubated for $72 \mathrm{~h}$ and $0.5 \mu \mathrm{Ci}$ / $\mathrm{ml}\left[{ }^{3} \mathrm{H}\right]$ thymidine was included from 48 to $72 \mathrm{~h}$ after the addition of the mitogen as described by Mead and Fausto (21). $\left[{ }^{3} \mathrm{H}\right]$ Thymidine incorporation was measured at $72 \mathrm{~h}$ as described by McNiel et al. (22). For the measurement of labeling index, bromodeoxyuridine (Amersham Corp., Arlington Heights, IL) was included from 48 to $72 \mathrm{~h}$, and labeled nuclei were stained with antibromodeoxyuridine antibody according to the manufacturer's instructions. In preliminary experiments, we compared labeling indexes measured by bromodeoxyuridine method and by conventional $\left[{ }^{3} \mathrm{H}\right]$ thymidine method $(23)$, and the values were essentially identical.

Iodination of activin A and determination of binding. Activin A ( 10 $\mu \mathrm{g}$ ) was iodinated with $\mathrm{Na}\left[{ }^{125} \mathrm{I}\right]$ by the method of Bolton-Hunter (24) to a specific activity of $50-90 \mu \mathrm{Ci} / \mathrm{mg}$. [ $\left.{ }^{125} \mathrm{I}\right]$ Activin A was purified on a Sephadex G-25 column in $50 \mathrm{mM}$ phosphate buffer ( $\mathrm{pH} 7.4$ ) containing $1 \%$ bovine serum albumin. For the binding study, cells were plated in a $35-\mathrm{mm}$ collagen-coated dish at a density of $2 \times 10^{5}$ cells/ well. After the attachment, monolayer cells were incubated for $30 \mathrm{~min}$ at $37^{\circ} \mathrm{C}$ with binding buffer containing $50 \mathrm{mM}$ Hepes ( $\mathrm{pH} \mathrm{7.4),} 128$ $\mathrm{mM} \mathrm{NaCl}, 5 \mathrm{mM} \mathrm{KCl}, 1.2 \mathrm{mM} \mathrm{CaCl}_{2}, 5 \mathrm{mM} \mathrm{MgSO}_{4}$, and $0.5 \% \mathrm{BSA}$. Monolayer cells were then cooled down to $4^{\circ} \mathrm{C}$ and were incubated for $3.5 \mathrm{~h}$ at $4^{\circ} \mathrm{C}$ with binding buffer containing either $\left[{ }^{125} \mathrm{I}\right] \mathrm{TGF}-\beta$ or $\left[{ }^{125} \mathrm{I}\right]-$ activin $A$ in the presence or absence of unlabeled agents. At the end of incubation, cells were washed four times with ice-cold binding buffer and lysed with $1 \%$ Triton X-100.

Measurement of activity of activin A. Bioactivity of activin A was determined by measuring the ability to induce differentiation of murine erythroleukemia cells (6). Murine erythroleukemia cells (F5-5 cells) were incubated for $5 \mathrm{~d}$ in the presence of known amount of activin A or serially diluted conditioned medium. Differentiation of erythroleukemia cells was assessed by staining hemoglobin with dianisidine (6). To confirm that the differentiation-inducing activity was caused by activin, we examined whether or not the erythroid differentiation activity was blocked by follistatin, an activin binding protein that blocks the action of activin (16).

Riboprobe construction. Rat inhibin $\beta_{\wedge}$ probe was subcloned into pGEM 7Zf(-) plasmid (Promega Biotec, Madison, WI). The resultant construct was linearized with Pst 1 . The transcription with T7 RNA polymerase ( Takara, Tokyo, Japan) generated a 384-base riboprobe comprised of 43 bases on pGEM7Zf $(-)$ and 341 bases complementary to the rat inhibin $\beta_{\mathrm{A}}$ mRNA. Riboprobe synthesized with T7 RNA polymerase was labeled using [ ${ }^{32} \mathrm{P}$ ]UTP (New England Nuclear) for RNase protection assay and using $\left[{ }^{35}\right.$ S UTP (New England Nuclear) for in situ hybridization. At the end of transcription, $5 \mu \mathrm{g} \mathrm{DNase}$ I ( Takara) was added, the mixture was incubated at $37^{\circ} \mathrm{C}$, and labeled riboprobe was recovered by ethanol precipitation. [ $\left.{ }^{35} \mathrm{~S}\right] \mathrm{UTP}$-labeled riboprobe was further hydrolyzed in $80 \mathrm{mM} \mathrm{NaHCO}, 120 \mathrm{mM}$ $\mathrm{Na}_{2} \mathrm{CO}_{3}, 10 \mathrm{mM}$ dithiothreitol for $20 \mathrm{~min}$ at $60^{\circ} \mathrm{C}$, and was then recovered by ethanol precipitation.

Detection of $m R N A$ for Inhibin $\beta_{A}$ subunit by ribonuclease protection assay. Total RNA was extracted from cultured hepatocytes or liver after partial hepatectomy by the method of Chomzynski and Sacchi (25). RNase protection assay was performed using RPA II kit (Ambion Inc., Austin, TX) according to the manufacturer's instructions.
Briefly, $10 \mu \mathrm{g}$ of total RNA was hybridized with $5 \times 10^{5} \mathrm{cpm}$ of each ${ }^{32} \mathrm{P}$-labeled riboprobe for $16 \mathrm{~h}$ at $45^{\circ} \mathrm{C}$, followed by digestion with $R N a s e A$ and $R N a s e T 1$ at $37^{\circ} \mathrm{C}$. The resultant protected hybrids were isolated by ethanol precipitation and separated on a $5 \%$ polyacrylamide/8-M urea denaturing gel. Dried gel was exposed to Kodak XAR-2 film at $-80^{\circ} \mathrm{C}$ for autoradiogram.

In situ hybridization. In situ hybridization was performed in cultured hepatocytes. Briefly, cultured hepatocytes were fixed with $4 \%$ paraformaldehyde in PBS for $5 \mathrm{~min}$. After rinsing with PBS, cells were dehydrated in ethanol. Hybridization was performed for $16 \mathrm{~h}$ at $50^{\circ} \mathrm{C}$ using ${ }^{35} \mathrm{~S}$-labeled antisense RNA probes. Cells were washed $2 \times$ SSC containing $50 \%$ formamide at $50^{\circ} \mathrm{C}$ for $30 \mathrm{~min}$, and were treated with RNase A $(25 \mu \mathrm{g} / \mathrm{ml})$ for $30 \mathrm{~min}$ at $37^{\circ} \mathrm{C}$. After washing twice with $2 \times$ SSC for $20 \mathrm{~min}$ at $50^{\circ} \mathrm{C}$ and then twice with $0.2 \times$ SSC for $20 \mathrm{~min}$ at $50^{\circ} \mathrm{C}$, the slides were dehydrated in ethanol and coated with Kodak NTB-2 emulsion. The exposure time was 2 wk at $4^{\circ} \mathrm{C}$. To rule out false positive in situ hybridization, ${ }^{35} \mathrm{~S}$-labeled sense RNA probe for rat inhibin $\beta_{A}$ was examined in the same series of slides under identical conditions.

Analysis of $m R N A$ by reverse Transcription PCR. Double-stranded cDNA was synthesized from poly-A RNA obtained by using oligo deoxythymidylate latex (Takara) (26). To avoid contamination of genomic DNA, samples with or without treatment of Moloney murine leukemia virus were prepared. One tenth of the resulting CDNA was used as a template for PCR. Oligonucleotide primers were designed on the basis of DNA sequence of rat inhibin subunits (27). The sense and antisense primers for inhibin $\alpha$ were 5'-TGACTTCAGCCCAGCTGTGG-3' and 5'-TTCACCGGCCCAGGGTTCAG-3', respectively. The sense and antisense primers for inhibin $\beta_{A}$ were 5'-GAACAGTGCCAGGAGAGCGG-3' and 5'-AGGTTGGCAAAGGGGCTGTG-3', respectively. For inhibin $\beta_{3}$, the sense and antisense primers were 5'-GTGGTGCCTGTGTTCGTGGA-3' and 5'-TTCACCGGCCCAGGGTTCAG-3', respectively. Random hexamer (Pharmacia Fine Chemicals, Piscataway, NJ) was used to generate cDNA fragment. The temperature program for the amplification was 30 cycles of $1 \mathrm{~min}$ at $94^{\circ} \mathrm{C}, 1 \mathrm{~min}$ at $60^{\circ} \mathrm{C}$, and $1 \mathrm{~min}$ at $72^{\circ} \mathrm{C}$. The products were separated on a $2 \%$ agarose gel and visualized with eithidium bromide.

\section{Results}

Effect of activin A on DNA synthesis in cultured rat heptocytes. In the presence of insulin, EGF induced 10-fold increase in DNA synthesis as assessed by $\left[{ }^{3} \mathrm{H}\right]$ thymidine incorporation in cultured hepatocytes. As demonstrated in Table I, $1 \mathrm{nM}$ activin A almost completely blocked DNA synthesis induced by EGF. The inhibitory effect was comparable to that of 100 pM TGF-

Table I. Effect of Activin A on DNA Synthesis Induced by EGF and $H G F$

\begin{tabular}{lcc}
\hline \multicolumn{1}{c}{ Addition } & Nuclear labeling $(\%)$ & {$\left[{ }^{3} \mathrm{H}\right]$ Thymidine incorporation } \\
\hline & & $c p m \times 10^{-4} /$ well \\
None & $4.3 \pm 1.2$ & $0.11 \pm 0.02$ \\
EGF & $47.0 \pm 5.4$ & $2.05 \pm 0.12$ \\
+Activin A (1 nM) & $9.4 \pm 0.9$ & $0.25 \pm 0.09$ \\
+TGF- $\beta$ (0.1 nM) & $1.8 \pm 0.2$ & $0.12 \pm 0.02$ \\
HGF/scatter factor & $31.0 \pm 6.5$ & $1.45 \pm 0.10$ \\
+Activin A (1 nM) & $2.9 \pm 0.2$ & $0.10 \pm 0.01$ \\
\hline
\end{tabular}

Hepatocytes were cultured for $72 \mathrm{~h}$ in medium containing $0.1 \% \mathrm{BSA}$, $0.1 \mathrm{nM}$ insulin, and agents indicated above. BrdU labeling and $\left[{ }^{3} \mathrm{H}\right]$ thymidine incorporation were measured at $72 \mathrm{~h}$ as described in Methods. Values are the mean \pm SE for three to four determinations and the representative of four experiments with similar results. 
$\beta$. In some cell systems, some, but not all, actions of activin A are reversed by inhibin. In addition, immunoreactive inhibin exists in pancreatic islets, and there is a possibility that inhibin is delivered to hepatocytes via portal vein (unpublished observation). Therefore, we tested whether inhibin A affected growth inhibitory effect of activin A in cultured rat hepatocytes. Up to $50 \mathrm{nM}$ inhibin A did not affect growth of hepatocytes by itself, nor did it affect DNA synthesis inhibited by 1 $\mathrm{nM}$ activin A (data not shown). Fig. 1 depicts dose-response relationship for the activin action on EGF-induced DNA synthesis. The growth inhibitory effect of activin A was dose-dependent, being detectable at $0.1 \mathrm{nM}$ and the maximal at $5 \mathrm{nM}$. In the presence of high concentrations of activin A, DNA synthesis was reduced to $\sim 5 \%$. When hepatocytes were incubated with $\mathrm{HGF}$ /scatter factor, HGF/scatter factor caused a sixfold stimulation of DNA synthesis. Activin A also inhibited HGFinduced DNA synthesis. Fig. 1 also demonstrates dose-response relationship for the activin A action on HGF-induced DNA synthesis. Comparing with the action on EGF-induced DNA synthesis, activin A was slightly more potent in inhibiting HGF-induced DNA synthesis. Thus, inhibitory effect was observed at a concentration of $10^{-11} \mathrm{M}$ and $10^{-10} \mathrm{M}$ activin inhibited DNA synthesis by $\sim 50 \%$. When hepatocytes were incubated with $1 \mathrm{nM}$ EGF, labeling index was increased to $47.0 \pm 5.4 \%($ mean $\pm \mathrm{SE}, n=4)$. In the presence of $1 \mathrm{nM}$ activin A, labeling index was reduced to $9.4 \pm 0.9 \%$ ( Table I). Likewise, $10 \mathrm{ng} / \mathrm{ml} \mathrm{HGF}$ increased nuclear labeling to $31.0 \pm 6.5 \%$. Again, $1 \mathrm{nM}$ activin A reduced HGF-mediated nuclear labeling to $2.9 \pm 0.2 \%$ ( Table $\mathrm{I}$ ). When activin A was added to medium without above mentioned mitogens, activin A did not cause any change in DNA synthesis by itself (data not shown). Follistatin is a protein that binds to activin $A$ in one to one stoichiometry and neutralizes the effect of activin A (16). 1 nmol follistatin blocked the growth inhibitory effect of $1 \mathrm{nM}$ activin $\mathrm{A}$ in cultured hepatocytes (data not shown).

Time course of inhibitory action of activin A on DNA synthesis by activin $A$. The maximum rate of DNA synthesis induced by EGF was observed between 48 and $72 \mathrm{~h}$ after the addition of the growth factor. To determine the critical period in which activin A elicits its inhibitory action in hepatocytes, activin A was added at various time points after the addition of EGF, and

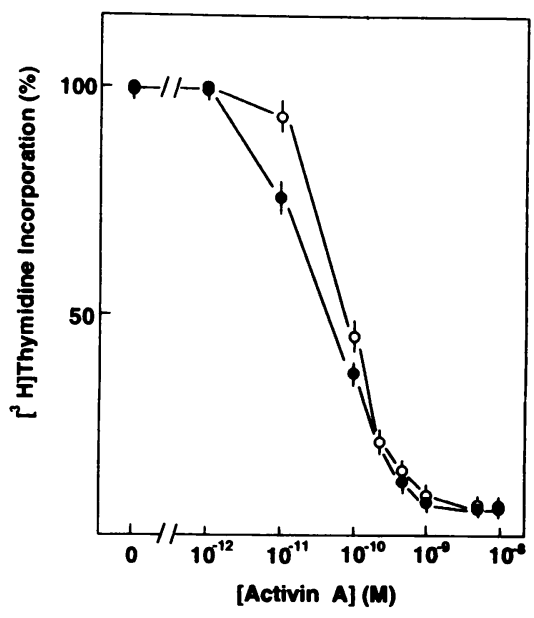

Figure 1. Dose-response relationship for the effect of activin $A$ on EGF- and HGF-induced DNA synthesis. Hepatocytes were incubated with either $1 \mathrm{nM}$ $\mathrm{EGF}(\mathrm{O})$ or $10 \mathrm{ng} / \mathrm{ml}$ HGF/scatter factor $(\bullet)$, $0.1 \mathrm{nM}$ insulin and various concentrations of activin A for $72 \mathrm{~h}$. $\left[{ }^{3} \mathrm{H}\right.$ ] Thymidine was added at $48 \mathrm{~h}$ and $\left[{ }^{3} \mathrm{H}\right]-$ thymidine incorporation was measured at 72 h. Values are the mean \pm SE for four ex-

periments. $\left[{ }^{3} \mathrm{H}\right]$ Thymidine incorporation in response to EGF alone and HGF/scatter factor alone were $21,436 \pm 1,053 \mathrm{cpm}$ and

$15,140 \pm 1,123 \mathrm{cpm}$ ( mean $\pm \mathrm{SE})$, respectively.

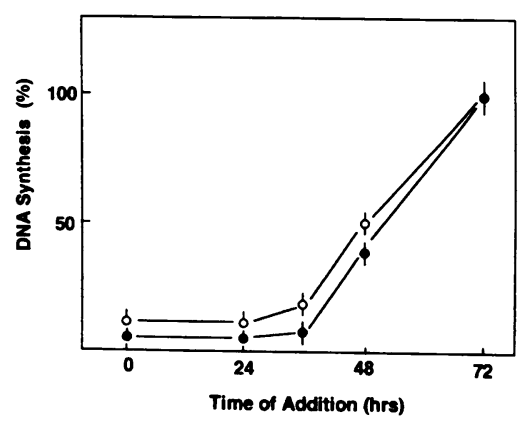

Figure 2. Time required for activin A and TGF$\beta$ to inhibit EGF-induced DNA synthesis. Hepatocytes were incubated with $1 \mathrm{nM}$ EGF and $0.1 \mathrm{nM}$ insulin and either $1 \mathrm{nM}$ activin $\mathrm{A}$ (o) or $0.1 \mathrm{nM}$ TGF- $\beta_{1}$ $(\bullet)$ was added at indicated time. Cells were cultured until $72 \mathrm{~h}$ and $\left[{ }^{3} \mathrm{H}\right]$ thymidine incorporation was measured at $72 \mathrm{~h}$. Values are the mean \pm SE for three experiments each done in quadruplicate. $\left[{ }^{3} \mathrm{H}\right]$ Thymidine incorporation in the absence of activin A or TGF- $\beta$ was $25,642 \pm 1,201 \mathrm{cpm}$ (mean \pm SE).

the changes in EGF-induced DNA synthesis were determined. TGF- $\beta$ was also tested to compare with the action of activin A. Activin A was fully effective in inhibiting DNA synthesis, even when added $36 \mathrm{~h}$ after the addition of EGF (Fig. 2). When added after $48 \mathrm{~h}$, the inhibitory effect was $\sim 50 \%$. The temporal pattern of the action of activin A was quite similar to that of TGF- $\beta$, and TGF- $\beta$ completely inhibited DNA synthesis when added $36 \mathrm{~h}$ after the addition of EGF.

Binding properties of activin $A$ and TGF- $\beta$. As mentioned above, effect of activin A was quite similar to that of TGF- $\beta$. To rule out a possibility that activin A inhibits DNA synthesis by acting on the TGF- $\beta$ receptor, we studied the binding of TGF- $\beta$ and activin A. Fig. $3 A$ depicts specific binding of $\left[{ }^{125} \mathrm{I}\right]$ TGF- $\beta$. $\left[{ }^{125} \mathrm{I}\right] \mathrm{TGF}-\beta$ binding was replaced by unlabeled TGF- $\beta$ in a dose-dependent manner. However, activin A did not affect the binding of $\left[{ }^{125} \mathrm{I}\right] \mathrm{TGF}-\beta$ at concentrations $\leq 10^{-8} \mathrm{M}$. Fig. $3 \mathrm{~B}$ demonstrates the binding of $\left[{ }^{125} \mathrm{I}\right]$ activin $A$ in hepatocytes. Again, binding of $\left[{ }^{125} \mathrm{I}\right]$ activin $\mathrm{A}$ was effectively inhibited by unlabeled activin A, however, TGF- $\beta$ had no effect on the binding of $\left[{ }^{125} \mathrm{I}\right]$ activin A. Similar results were obtained in hepatocytes cultured for $48 \mathrm{~h}$ (data not shown).

Production of activin $A$ in hepatocytes. It is known that activin A acts as an autocrine or a paracrine factor in some cell systems (27-29). We then examined whether activin A was produced in hepatocytes. Bioactivity of activin A was determined by measuring the ability to induce differentiation of erythroleukemia cells (6). Bioactivity of activin A was detected in conditioned medium of hepatocytes incubated with EGF. Fig. 4 demonstrates the time course of changes in activin $\mathrm{A}$ activity in conditioned medium of hepatocytes. Bioactivity of activin was not detected in conditioned medium of EGFtreated cells within $24 \mathrm{~h}$. However, considerable bioactivity appeared after $48 \mathrm{~h}$ or later, whereas bioactivity was not detected in cells incubated without EGF. Similarly, bioactivity of activin A was detected in cells stimulated by $\mathrm{HGF} /$ scatter factor (data not shown). Fig. 5 depicts expression of mRNA for $\beta_{A}$ subunit of activin measured by ribonuclease protection assay in hepatocytes treated with EGF. mRNA for $\beta$ increased markedly in cells incubated with EGF for $48 \mathrm{~h}$. It should be mentioned that mRNAs for $\alpha$ and $\beta_{\mathrm{B}}$ subunits of inhibin were not expressed in hepatocytes when analyzed by reverse transcription PCR (data not shown). These results indicate that activin $A$ is produced in hepatocytes stimulated to proliferate by EGF. Bioactivity of activin A was not detected in conditioned me- 

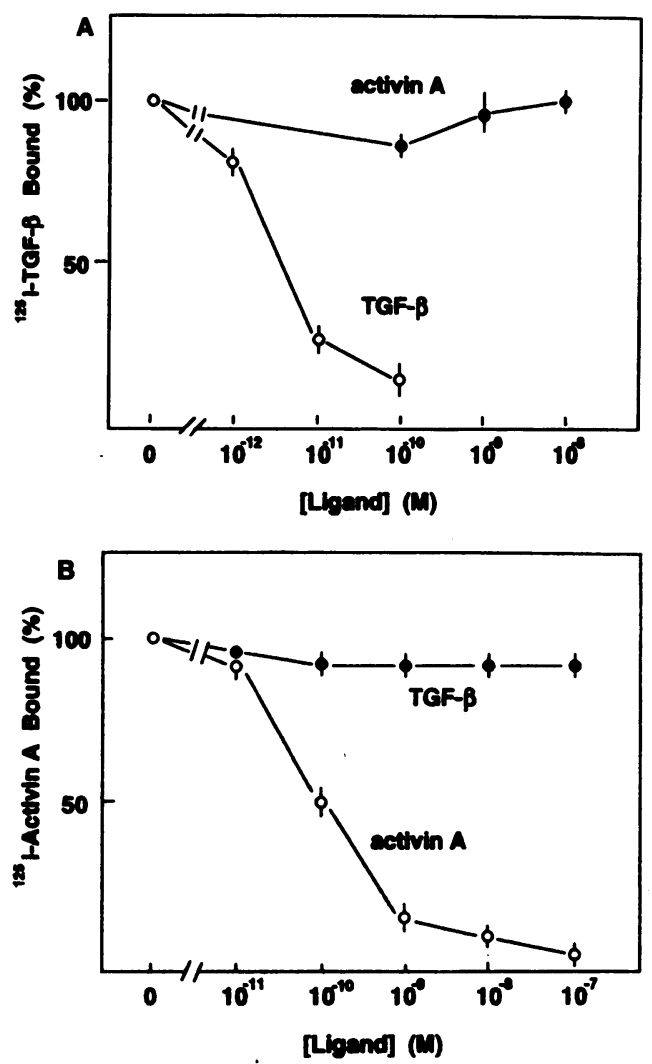

Figure 3. Binding of $\left[{ }^{125} \mathrm{I}\right]$ activin $\mathrm{A}$ and $\left[{ }^{125} \mathrm{I}\right] \mathrm{TGF}-\beta$. Hepatocytes were incubated at $4^{\circ} \mathrm{C}$ for $3.5 \mathrm{~h}$ with either $\left[{ }^{125} \mathrm{I}\right] \mathrm{TGF}-\beta(A)$ or $\left[{ }^{125} \mathrm{I}\right]-$ activin $A(B)$ in the presence of various concentrations of unlabeled ligands. Cells were washed and radioactivity bound was determined. Values are the mean \pm SE for four determinations and representative of three experiments with similar results.

dium of nonparenchymal cells. To further confirm that activin A was produced in parenchymal cells, we measured mRNA expression of $\beta_{A}$ subunit by in situ hybridization in cultured hepatocytes. As shown in Fig. 6, the signal was detected in cultured parenchymal cells. No signal was detected when the sense probe was used. Furthermore, $\beta_{A}$ mRNA was not expressed in non-parenchymal cells even when they were cocultured with parenchymal cells (data not shown).

To assess whether endogenously produced activin A actually modifies growth of hepatocytes, we examined the effect of an activin-binding protein follistatin, which blocks the action

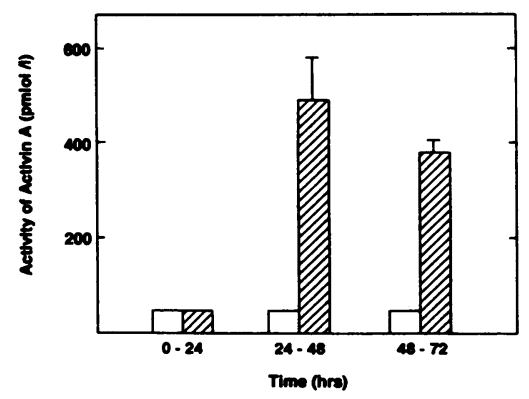

Figure 4. Release of bioactivity of activin $A$ from hepatocytes. Hepatocytes were cultured with $0.1 \mathrm{nM}$ insulin in the presence $(\square)$ and absence ( $\square$ ) of $1 \mathrm{nM}$ EGF and culture medium was changed every $24 \mathrm{~h}$. Bioactivity of activin $A$ in medium was determined by measur-

ing differentiation-inducing activity in erythroleukemia cells as described in Methods. Values are the mean $\pm \mathrm{SE}$ for three experiments each done in quadruplicate.

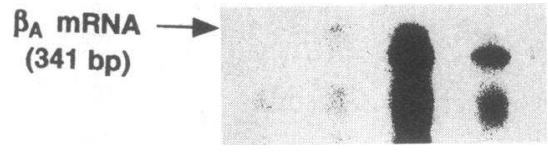

Figure 5. Expression of mRNA for $\beta_{A}$-subunit. Hepatocytes were cultured with $1 \mathrm{nM}$ EGF and $0.1 \mathrm{nM}$ insulin for indicated time. Total mRNA was extracted and mRNA for $\beta_{A}$ subunit was measured by

$\begin{array}{llll}0 & 24 & 48 & 72\end{array}$ ribonuclease protection Time (hrs) assay as described in Methods.

of activin A (16). As demonstrated in Fig. 7, basal $\left[{ }^{3} \mathrm{H}\right]$ thymidine uptake increased slightly as a function of cell density. EGF increased $\left[{ }^{3} \mathrm{H}\right]$ thymidine incorporation at any cell density, but the stimulatory action of EGF was attenuated at a high cell density. Follistatin significantly enhanced EGF-mediated DNA synthesis, and the stimulatory action of follistatin was observed even in hepatocytes cultured in a high cell density.

Expression of mRNA for $\beta_{A}$ subunit in regenerating liver. To examine whether activin $A$ was expressed in hepatocytes in vivo, we measured mRNA expression of $\beta_{A}$ subunit in liver after partial hepatectomy. As depicted in Fig. 8, mRNA for $\beta_{A}$ subunit was expressed slightly in intact liver and disappeared at $12 \mathrm{~h}$. The mRNA expression was then markedly increased $24 \mathrm{~h}$ after the hepatectomy and was declined thereafter. These results suggest that activin $\mathrm{A}$ is produced in liver after partial hepatectomy.

\section{Discussion}

Results of the present study indicate that activin A inhibits initiation of DNA synthesis in rat hepatocytes in primary culture. The inhibitory effect is detected at subnanomolar range and, at a concentration of $5 \mathrm{nM}$, activin A virtually blocks growth promoting actions of both EGF and HGF/scatter factor. In this regard, the effect of activin A resembles that of TGF- $\beta$, even though activin A concentrations to block growth of hepatocytes are higher. Furthermore, both activin $A$ and TGF- $\beta$ are fully effective in blocking DNA synthesis when added $36 \mathrm{~h}$ after the addition of EGF. The results raise a possibility that both factors exert their effects by acting on the same point of cell cycle, locating in the middle to late $G_{1}$ phase, by a common or similar mechanism. As shown in Fig. 3, both factors bind to their own receptors without affecting the binding of each other. Therefore, each factor inhibits growth of hepatocytes through their own receptors. Recent cDNA cloning of receptors for activin $A$ and TGF- $\beta$ indicates that they have closely related primary structures $(30,31)$ : both have a single transmembrane domain and both of their intracellular domains contain predicted serine/threonine kinase activity. It is possible that both factors inhibit growth of hepatocytes by using a similar intracellular mechanism. It should be mentioned that, despite structural homology in their receptors, two factors also elicit distinct actions. For example, activin A causes glycogenolysis in hepatocytes by activating phospholipase $\mathrm{C}$ while TGF- $\beta$ does not (12). Hence, the activin A receptor activates at least two intracellular pathways, one is similar or common to the action of TGF- $\beta$ and the other is unique to activin A. 


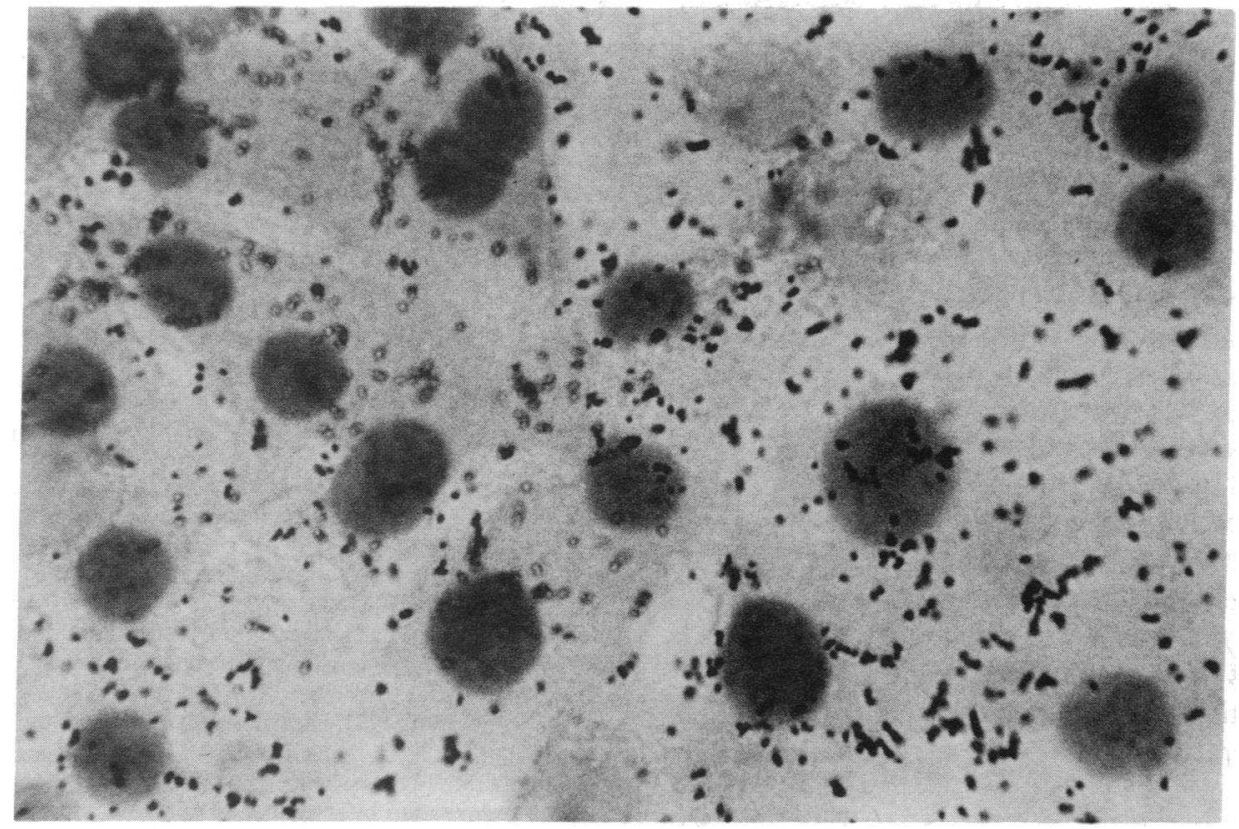

Figure 6. In situ hybridization of $\beta_{\Lambda}$-subunit in cultured hepatocytes. $\mathrm{Pa}$ renchymal cells were cultured with EGF for $48 \mathrm{~h}$ and in situ hybridization of $\beta_{A}$-subunit was done as described in Methods.
The present results provide for the first time evidence that activin $A$ is produced in parenchymal liver cells. Of particular interest is the fact that activin $A$ is released when growth of hepatocytes is induced by an addition of EGF or HGF/scatter factor. In addition, production of activin A becomes detectable later than $24 \mathrm{~h}$ of the addition of EGF. As shown in Fig. 2, activin A inhibits initiation of DNA synthesis by acting on a point located after $36 \mathrm{~h}$ of the addition of EGF. Taken together, activin $A$ is produced at time when it exerts the inhibitory effect on DNA synthesis. Therefore, it is likely that activin A acts as a negative regulator of cell growth in hepatocytes. As shown in Fig. 7, follistatin, which blocks the action of activin A (16), augments EGF-induced DNA synthesis. This result supports the notion that endogenously produced activin $A$ attenuates EGF-mediated DNA synthesis in cultured hepatocytes. It is

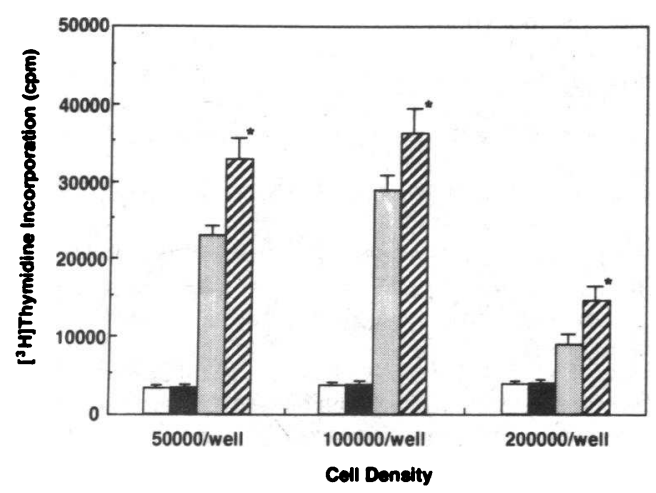

Figure 7. Effect of follistatin on EGF-induced DNA synthesis in hepatocytes. Hepatocytes were cultured in three different cell densities and were incubated with $1 \mathrm{nM} E G F$ and $0.1 \mathrm{nM}$ insulin in the presence and absence of $1 \mathrm{nM}$ follistatin. $\left[{ }^{3} \mathrm{H}\right]$ Thymidine was added at $48 \mathrm{~h}$ and $\left[{ }^{3} \mathrm{H}\right]$ thymidine incorporation was measured at $72 \mathrm{~h}$. Values are the mean $\pm \mathrm{SE}$ for four determinations and the representative of four experiments with similar results. Statistical analysis was done by using Student's $t$ test. ${ }^{*} P<0.01$ vs EGF. $\square$, None; $\square$, follistatin; $\square$, EGF, $\square$, EGF + follistatin. quite likely that endogenous activin A acts as an autocrine inhibitor of initiation of DNA synthesis in hepatocytes, production of which is turned on by the stimulator of cell growth.

The role of activin $A$ as an autocrine inhibitor of DNA synthesis in hepatocytes is intriguing in view of the history of the research for liver chalones. In the 1950s, hypotheses as to tissue homeostasis were proposed based on the presence of stimulators or inhibitors of cell growth. If the inhibitor is produced by the differentiated hepatocytes, partial hepatectomy would decrease the concentration of the inhibitor and cells start proliferation. Subsequently, the cell number is increased and the concentration of the inhibitor becomes high enough to block cell growth. According to this "chalone" hypothesis (32), rate of cell proliferation is under the control of a tissue-specific factor named chalone, which inhibits cell proliferation. Attempts were made to identify the putative liver chalone (33-35), but the nature of chalone remained unknown. Leffert and Weinstein (36) suggested very low density lipoprotein to be a candidate for the liver chalone. Our present results indicate that activin $A$ also acts as a liver chalone. Interestingly, mRNA for $\beta_{A}$ disappears shortly after hepatectomy and is then markedly increased $24 \mathrm{~h}$ after hepatectomy.

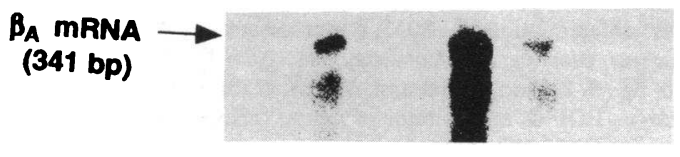

$\begin{array}{lllll}0 & 12 & 24 & 48 & 72\end{array}$

Time (hrs)

Figure 8. Time course of expression of mRNA for $\beta_{A}$ subunit in liver after partial hepatectomy. Male Wistar rats were partially hepatectomized and total RNA was extracted from liver before and after the partial hepatectomy. mRNA for $\beta_{\Lambda}$ was analyzed by ribonuclease protection assay as described in Methods. 
During liver regeneration, various stimulators of growth of hepatocytes are induced. Transforming growth factor- $\alpha$, which acts on EGF receptor to stimulate hepatocyte growth, is produced in parenchymal liver cells as an autocrine factor (21), while HGF/scatter factor is synthesized in nonparenchymal liver cells (37). Subsequently, TGF- $\beta$, a potent inhibitor of hepatocyte growth, is synthesized in nonparenchymal cells (14). TGF- $\beta$ is produced as an inactive form, and it is postulated that TGF- $\beta$ is taken up into parenchymal cells via the IGF II/mannose 6-phosphate receptor (38), where TGF- $\beta$ is activated by a mechanism involving proteolysis. Our present results provide another aspect of regulation of growth of hepatocytes. When hepatocytes are stimulated by growth factors such as TGF- $\alpha$ and HGF, activin A is synthesized after a certain lag period in parenchymal liver cells. Activin A may act as an autocrine growth inhibitor of parenchymal liver cells to terminate growth. Hence, growth of hepatocytes is regulated under a dual negative control of two members of a TGF- $\beta$ supergene family, activin A and TGF- $\beta$. The positive and negative regulations involve autocrine and paracrine mechanisms.

\section{Acknowledgments}

Authors thank Ms. Romi Nobusawa for her secretarial assistance during the preparation of the manuscript.

The present study was supported in part by Grants-in-Aid for Scientific Research from The Ministry of Education, Science and Culture of Japan, and by grants from The Mochida Foundation and The Kanae Foundation.

\section{References}

1. Vale, W., J. Rivier, J. Vaughan, R. McClintok, A. Corrigan, W. Woo, D. Karr, and J. Spiess. 1986. Purification and characterization of FSH releasing protein from porcine ovarian follicular fluid. Nature (Lond.). 321:776-779.

2. Katayama, T., K. Shiota, and M. Takahashi. 1990. Activin A increases the number of follicle-stimulating hormone cells in anterior pituitary cultures. $\mathrm{Mol}$. Cell. Endocrinol. 69:179-185.

3. Sugino, H., T. Nakamura, Y. Hasegawa, K. Miyamoto, Y. Abe, M. Igarashi, Y. Eto, H. Shibai, and K. Titani. 1988. Erythroid differentiation factor can modulate follicular granulosa cell functions. Biochem. Biophys. Res. Commun. 153:281-288.

4. Xiao, S., J. K. Findlay, and D. M. Robertson. 1990. The effect of bovine activin and follicle-stimulating hormone (FSH) suppressing protein/follistatin on FSH-induced differentiation of rat granulosa cells in vitro. Mol. Cell. Endcrinol. 69:1-8.

5. Eto, Y., T. Tsuji, M. Kakegawa, S. Takano, T. Yakagawa, and H. Shibai. 1987. Purification and characterization of erythroid differentiation factor isolated from human leukemia cell line, THP-1. Biochem. Biophys. Res. Commun. 42:1095-1100.

6. Schubert, D., H. Kimura, M. LaCorbiere, J. Vaughan, D. Karr, and W. H. Fischer. 1990. Activin is a nerve cell servival molecule. Nature (Lond.). 344:868870.

7. Nishimura, M., K. Kaku, Y. Azuno, K. Okafuji, Y. Eto, M. Shiozaki, H Sasaki, T. Inoue, and T. Kaneko. 1991. Effect of erythroid differentiation factor on megakaryocytic differentiation of L8057, a murine megakaryoblastic leukemia cell line. Biochem. Biophys. Res. Commun. 181:1042-1047.

8. Hashimoto, M., S. Kondo, T. Sakurai, Y. Eto, H. Shibai, and M. Muramatsu. 1990. Activin/EDF as an inhibitor of neural differentiation. Biochem. Biophys. Res. Commun. 173:193-200.

9. Smith, J. C., B. M. J. Price, K. Van Nimmen, and D. Huylebroeck. 1990. Identification of a potent xenopus mesoderm-inducing factor as a homologue of activin A. Nature (Lond.). 345:729-734.

10. Green, J. B. A., and J. C. Smith. 1990. Graded changes in dose of a xenopus activin A homologue elicit stepwise transitions in embryonic cell fate. Nature (Lond.). 347:391-394.

11. Sokol, S., and D. A. Melton. 1991. Pre-existent pattern in xenopus animal pole cells revealed by induction with activin. Nature (Lond.). 351:409-411.
12. Mine, T., I. Kojima, and E. Ogata. 1989. Stimulation of glucose production by activin A in isolated hepatocytes. Endocrinology. 125:586-591.

13. Nakamura, T., Y. Tomita, R. Hirai, K. Yamaoka, K. Kaji, and A. Ichihara. 1985. Inhibitory effect of transforming growth factor- $\beta$ on DNA synthesis of rat hepatocytes in primary culture. Biochem. Biophys. Res. Commun. 133:10421050.

14. Braun, L., J. E. Mead, M. Panzica, R. Mikumo, G. I. Bell, and N. Fausto. 1988. Transforming growth factor $\beta$ mRNA increases during liver regeneration: a possible paracrine mechanism of growth regulation. Proc. Natl. Acad. Sci. USA. 85:1539-1543.

15. Murata, M., K. Onomichi, Y. Eto, H. Shibai, and M. Muramatsu. 1988. Expression of erythroid differentiation factor in chinese hamster ovary cells. Bio chem. Biophys. Res. Commun. 151:230-235.

16. Nakamura, T., K. Takio, Y. Eto, H. Shibai, K. Titani, and H. Sugino. 1990. Activin-binding protein from rat ovary is follistatin. Science (Wash. DC). 247:836-838.

17. Fukuda, M., K. Miyamoto, Y. Hasegawa, M. Nomura, M. Igarashi, K. Kangawa, and $\mathrm{H}$. Matsuo. 1986. Isolation of bovine follicular fluid inhibin of about $32 \mathrm{KDa}$. Mol. Cell. Endocrinol. 44:55-60.

18. Berry, M. N., and D. S. Friend. 1969. High-yield preparation of isolated rat liver parenchymal cells. J. Cell Biol. 43:506-520.

19. Shimaoka, S., T. Makamura, and A. Ichihara. 1987. Stimulation of growth of primary cultured adult rat hepatocytes without growth factor by coculture with non-parenchymal liver cells. Exp. Cell. Res. 172:228-242.

20. Higgins, G. M., and R. M. Anderson. 1931. Experimental pathology of the liver. Arch. Pathol. 12:186-202.

21. Mead, J. E., and N. Fausto. 1989. Transforming growth factor $\alpha$ may be a physiological regulator of liver regeneration by means of an autocrine mechanism. Proc. Natl. Acad. Sci. USA. 86:1558-15562.

22. McNiel, P. L., M. P. McKenna, and D. L. Taylor. 1985. A transient rise in cytosolic calcium follows stimulation of quiescent cells with growth factors and is inhibitable with phorbol myristate acetate. J. Cell Biol. 101:372-379.

23. Pledger, W. J., C. D. Stiles, H. N. Antoniades, and C. D. Scher. 1978. An ordered sequence of events is required before BALB/c 3T3 cells become committed to DNA synthesis. Proc. Natl. Acad. Sci. USA. 75:2839-2843.

24. Bolton, A. E., and W. M. Hunter. 1973. The labelling of proteins to high specific radioactivities by conjugating to a ${ }^{125}$ I-containing acylating agent. Bio chem. J. 133:529-539.

25. Chomzynski, P., and N. Socchi. 1987. Single-step method of RNA isolation by acid guanidinium thiocyanate-phenol-chloroform extraction. Anal. Biochem. 162:156-159.

26. Kuribayashi, K. 1988. A simple and very efficient method for nucleic acid. Nucleic Acids Res. 19:61-64.

27. Esch, F. S., S. Shimasaki, K. Cooksey, M. Mercado, A. J. Mason, Y. Y. Ying, N. Ueno, and Y. Ling. 1987. Complimentary deoxyribonucleic acid (cDNA) cloning and DNA sequence analysis of rat ovarian inhibins. Mol. Endocrinol. 1:388-396.

28. Hillier, S. G. 1991. Regulatory functions for inhibin and activin in human ovaries. J. Endocrinol. 131:171-175.

29. Corrigan, A. Z., L. M. Bilezikijan, R. S. Carroll, L. N. Bold, C. H. Schmelzer, B. M. Ferdly, A. J. Mason, W. W. Chin, R. H. Schwall, and W. Vale. 1991. Evidence for an autocrine role of activin B within rat anterior pituitary cultures. Endocrinology. 128:1682-1684.

30. Mathews, L. S., and W. W. Vale. 1991. Expression cloning of an activin receptor, a predicted transmembrance serine kinase. Cell. 65:973-982.

31. Lin, H. Y., X.-F. Wang, E. Ng-Eaton, R. A. Weinberg, and H. F. Lodish. 1992. Expression cloning of the TGF- $\beta$ type II receptor, a functional transmembrane serine/threonine kinase. Cell. 68:775-785.

32. Bullough, W. S. 1962. Control of mitotic activity in adult mammalian tissues. Biol. Rev. Camb. Philos. Soc. 37:307-342.

33. Nadal, C. 1979. Control of liver growth by growth inhibitors (chalones). Arch. Toxicol. 35(Suppl. 2):131-142.

34. Deschamps, Y., and W. G. Verly. 1975. The hepatic chalone. Biomedicine (Paris) 22:195-208.

35. McMahon, J. B., J. G. Farrelly, and P. T. Iype. 1982. Purification and properties of a rat liver protein that specifically inhibits the proliferation of nonmalignant epithelial cells from liver. Proc. Natl. Acad. Sci. USA. 79:456-460.

36. Leffert, H. L., and D. B. Weinstein. 1976. Growth control of differentiated fetal rat hepatocytes in primary culture. J. Cell Biol. 70:20-32.

37. Noji, S., K. Tashiro, E. Koyama, T. Nohno, K. Ohyama, S. Taniguchi, and T. Nakamura. 1990. Expression of hepatocyte growth factor gene in endothelial and Kupffer cells of damaged rat livers, as revealed by In Situ hybridization. Biochem. Biophys. Res. Commun. 173:42-47.

38. Jirtle, R. L., B. I. Carr, and C. D. Scott. 1991. Modulation of insulin-like growth factor-II/mannose 6-phosphate receptor and transforming growth factor$\beta_{1}$ during liver regeneration. J. Biol. Chem. 266:22444-22450. 